\title{
Boosting of Antioxidants and Alkaloids in Catharanthus roseus Suspension Cultures Using Silver Nanoparticles with Expression of CrMPK3 and STR Genes
}

\author{
Ahmed Fouad ${ }^{1}$, Adel E. Hegazy ${ }^{2}$, Ehab Azab ${ }^{3}\left(\mathbb{D}\right.$, Ebtihal Khojah $^{3}$ and Tarek Kapiel ${ }^{1, *(\mathbb{D}}$ \\ 1 Botany and Microbiology Department, Faculty of Science, Cairo University, Cairo 12613, Egypt; \\ ahmedsfouad@yahoo.com \\ 2 Department of Plant Biotechnology, Genetic Engineering and Biotechnology Research Institute, \\ University of Sadat City, Sadat City 32897, Egypt; amradel807080@googlemail.com \\ 3 Department of Food Science and Nutrition, College of Sciences, Taif University, P.O. Box 11099, \\ Taif 21944, Saudi Arabia; e.azab@tu.edu.sa (E.A.); eykhojah@tu.edu.sa (E.K.) \\ * Correspondence: tkapiel@sci.cu.edu.eg
}

Citation: Fouad, A.; Hegazy, A.E.; Azab, E.; Khojah, E.; Kapiel, T. Boosting of Antioxidants and Alkaloids in Catharanthus roseus Suspension Cultures Using Silver Nanoparticles with Expression of CrMPK3 and STR Genes. Plants 2021, 10, 2202. https://doi.org/10.3390/ plants10102202

Academic Editors:

Iyyakkannu Sivanesan and Katarina Vogel-Mikuš

Received: 31 August 2021

Accepted: 13 October 2021

Published: 17 October 2021

Publisher's Note: MDPI stays neutral with regard to jurisdictional claims in published maps and institutional affiliations.

Copyright: (c) 2021 by the authors. Licensee MDPI, Basel, Switzerland. This article is an open access article distributed under the terms and conditions of the Creative Commons Attribution (CC BY) license (https:// creativecommons.org/licenses/by/ $4.0 /)$.

\begin{abstract}
Global agricultural systems are under unprecedented pressures due to climate change. Advanced nano-engineering can help increase crop yields while ensuring sustainability. Nanotechnology improves agricultural productivity by boosting input efficiency and reducing waste. Alkaloids as one of the numerous secondary metabolites that serve variety of cellular functions essential for physiological processes. This study tests the competence of silver nanoparticles (AgNPs) in boosting alkaloids accumulation in Catharanthus roseus suspension cultures in relation to the expression of $C$. roseus Mitogen Activated Protein Kinase 3 (CrMPK3) and Strictosidine Synthase (STR) genes. Five concentrations $\left(5,10,15,20\right.$ and $\left.25 \mathrm{mg} \cdot \mathrm{L}^{-1}\right)$ of AgNPs were utilized in addition to deionized water as control. Results reflected binary positive correlations among AgNPs concentration, oxidative stress indicated with increase in hydrogen peroxide and malondialdehyde contents, activities of ascorbate peroxidase and superoxide dismutase, expression of the regulatory gene CrMPK3 and the alkaloid biosynthetic gene STR as well as alkaloids accumulation. These correlations add to the growing evidence that AgNPs can trigger the accumulation of alkaloids in plant cells through a signaling pathway that involves hydrogen peroxide and MAPKs, leading to up-regulation of the biosynthetic genes, including STR gene.
\end{abstract}

Keywords: silver nanoparticles; Catharanthus roseus; $\mathrm{H}_{2} \mathrm{O}_{2}$; malondialdehyde; APX; SOD; CrMPK3; STR; alkaloids

\section{Introduction}

Catharanthus roseus, belonging to Apocynaceae is an essential medicinal plant synthesizing about 130 precious indole alkaloids [1], many of which are important for valuable drugs [2]. The common precursor for monoterpenoid indole alkaloids (strictosidine) is produced in the shikimate pathway step catalyzed by strictosidine synthases (STR) [3]. However, the low productivity and high cost of alkaloids chemical synthesis put $C$. roseus as an alternative source for industrial extraction of such invaluable secondary metabolites $[4,5]$.

Plant secondary metabolites, including alkaloids, are important for the plant to interact with its environment for adaptation and defense against different types of stress [6,7]. Heavy metals, at phytotoxic concentrations, bring about oxidative stress accompanied with motivation in reactive oxygen species (ROS) generation [8]. Besides provoking ascorbateglutathione cycle enzymes and other antioxidant enzymes [e.g., catalase (CAT), peroxidases (POD), and superoxide dismutase (SOD)]. Metabolic activities are directed towards pathways consuming reduction equivalents. Consequently, the biosynthetic pathways of reduced compounds, including alkaloids, are promoted $[9,10]$. The utilization of heavy 
metals to enhance alkaloids biosynthesis in C. roseus was recorded using $\mathrm{Mn}^{2+}, \mathrm{Pb}^{2+}$, and $\mathrm{Ni}^{2+}$ [11], $\mathrm{Hg}^{2+}$ [12], $\mathrm{Cu}^{2+}$ [3], $\mathrm{Cd}^{2+}$ [13], $\mathrm{Ag}^{+}$[14], $\mathrm{Co}^{2+}$ [15] and $\mathrm{Cr}^{2+}$ [16].

Mitogen-activated protein kinases (MAPKs) are a major group of protein kinases playing a crucial role in coupling the perception of stressful stimuli with alterations in gene expression [17]. MAPK cascade is fundamental for alkaloids biosynthesis while experiencing stress conditions [18]. Up-regulation of several genes related to alkaloids biosynthetic pathway coupled with stimulation of $C r M P K 3$ expression was recorded in $C$. roseus following copper treatments [3] and silver exposure [14].

Although stress promotes alkaloids production, it is usually associated with a decrease in growth of the producing plant that may neglect an increase in the total amount of alkaloids synthesized per plant [15]. Thus, stress should be manipulated to produce the maximum enhancement in alkaloids production with minimum growth retardation. Applying heavy metals, such manipulation can be achieved through variations in the used metal concentration and stressful treatment duration. The unique characteristics of nanoparticles, compared with their bulk counterparts, may provide an additional tool to manipulate heavy metal-associated stress [19].

Silver nanoparticles (AgNPs) offer a unique biological activity and can function as new stimulators for plant growth [20]. Positive effects of AgNPs include germination stimulus, revitalization of growth, accumulation of biomass, improved induction and proliferation of shoots or higher pigment content [21-23]. Several authors documented the potential use of AgNPs- enhance accumulation of secondary metabolites in tissue cultures of hazel [24], Cucumis anguria [25], Caralluma tuberculata [26], and Linum usitatissimum [27]. Nevertheless, few studies $[25,26]$ were devoted to monitoring the impact of AgNPs on alkaloids production in plant tissues and lacked elucidation for the genetic expression profile underlying the biosynthetic pathway.

Plant cell and tissue cultures are routinely utilized to study and enhance alkaloids production in C. roseus [28]. However, cell suspension culture is the start point for the establishment of bioreactors and commercial production of the precious metabolites [29].

The aim of this work is to study the positive potential effect of using AgNPs in the stimulation of alkaloids biosynthesis in C. roseus suspension cultures by triggering the expression of CrMPK3 and STR genes.

\section{Results}

\subsection{Growth Parameters}

Regarding the corresponding control, AgNPs have a growth-promoting effect at 5 mg. $\mathrm{L}^{-1}$ manifested in about $15 \%$ significant increase in both fresh and dry weights (Figure 1). Higher concentrations of AgNPs was associated with decrease in fresh weight reaching about $55 \%$ of the corresponding control at $25 \mathrm{mg} \mathrm{L}^{-1}$. Dry weight remained unaffected at $10 \mathrm{mg} \mathrm{L}^{-1}$ then decreased reaching about $73 \%$ of control at $15 \mathrm{mg} \mathrm{L}^{-1}$ that remained insignificantly changed with furthur increases in AgNPs concentration.

\subsection{Hydrogen Peroxide $\left(\mathrm{H}_{2} \mathrm{O}_{2}\right)$ Content and Lipid Peroxidation}

Compared with untreated cultures, AgNPs have no significant effect on $\mathrm{H}_{2} \mathrm{O}_{2}$ content at $5 \mathrm{mg} \mathrm{L}^{-1}$ (Figure 2a). However, the increase in AgNPs concentration was associated with a significant irregular increase in $\mathrm{H}_{2} \mathrm{O}_{2}$ content to be approximately doubled at $25 \mathrm{mg} \mathrm{L}^{-1}$. Lipid peroxidation, symbolized with malondialdehyde (MDA) content, exhibited a more or less similar trend following exposure to AgNPs (Figure 2b). It remained unaffected at $5 \mathrm{mg} \mathrm{L}^{-1}$ then increased at higher concentrations reaching about 1.75 fold control at $25 \mathrm{mg} \mathrm{L}^{-1}$. 


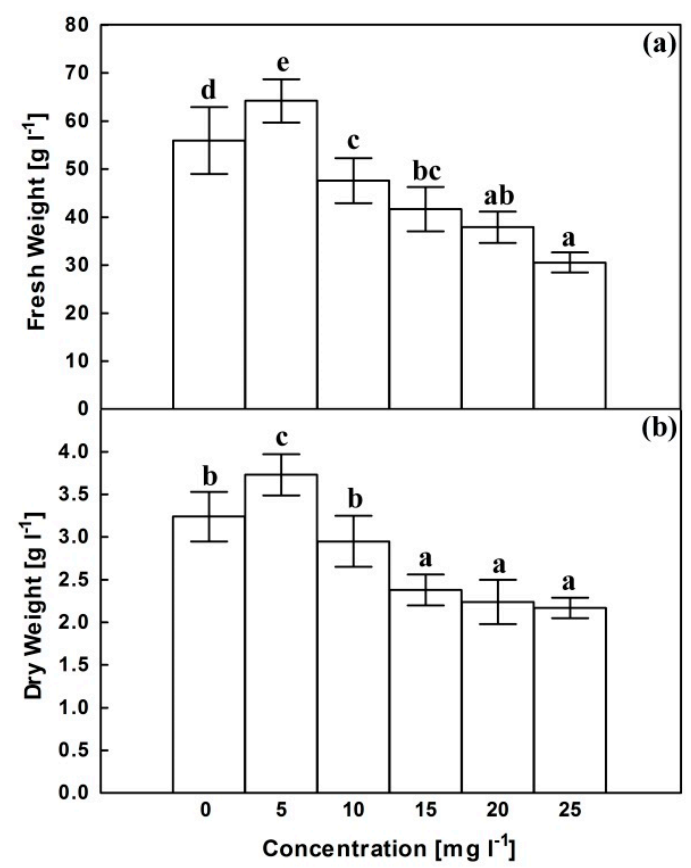

Figure 1. Effects of AgNPs at concentrations of 5, 10, 15, 20 and $25 \mathrm{mg} \mathrm{L}^{-1}$ on fresh weight (a) and dry weight (b) of $C$. roseus cell suspension cultures. Means \pm standard deviations (SDs), $n=3$, Values followed by the same small letter within each column are not significantly different at $p \leq 0.05$.

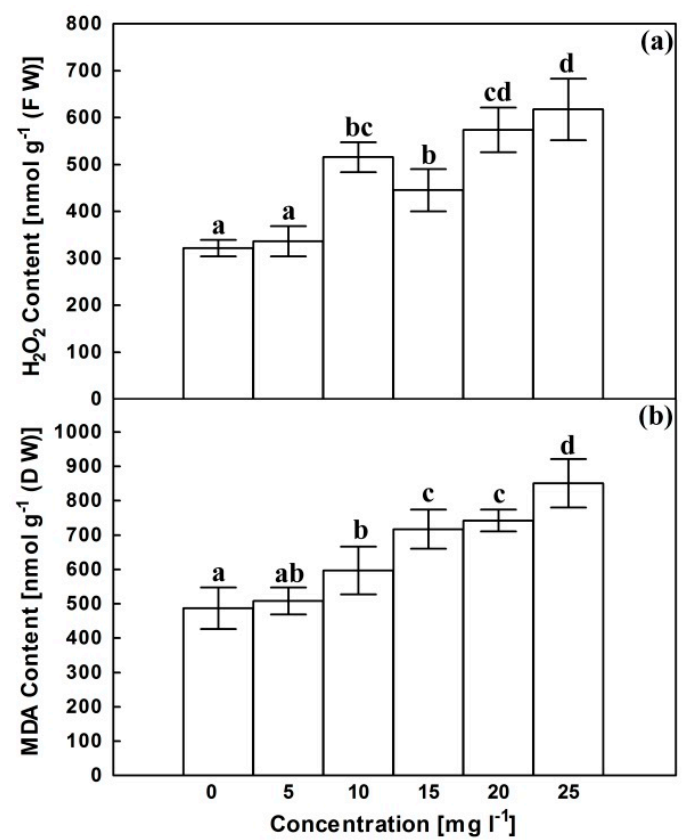

Figure 2. Effects of AgNPs at concentrations of 5, 10, 15, 20 and $25 \mathrm{mg} \mathrm{L}^{-1}$ on $\mathrm{H}_{2} \mathrm{O}_{2}$ content (a) and MDA content (b) of $C$. roseus cell suspension cultures. Means \pm standard deviations (SDs), $\mathrm{n}=3$, Values followed by the same small letter within each column are not significantly different at $p \leq 0.05$.

\subsection{Relative Expression of CrMPK3 and STR Genes}

Compared with the corresponding control, AgNPs did not aggravate the expression of the CrMPK3 gene at $5 \mathrm{mg} \mathrm{L}^{-1}$ (Figure 3a). The transcript abundance increased dramatically at 10 and $15 \mathrm{mg} \mathrm{L}^{-1}$ then steeply at higher concentrations reaching about 4.5 folds of control at $25 \mathrm{mg} \mathrm{L}^{-1}$. Similar to CrMPK3 gene, STR gene expression remained insignificantly affected at $5 \mathrm{mg} \mathrm{L}^{-1}$, compared with control expression (Figure $3 b$ ). However, the higher 
AgNPs concentrations were associated with a significant increase in STR transcript to reach a maximum of 3.1 folds of control at $20 \mathrm{mg} \mathrm{L}^{-1}$.

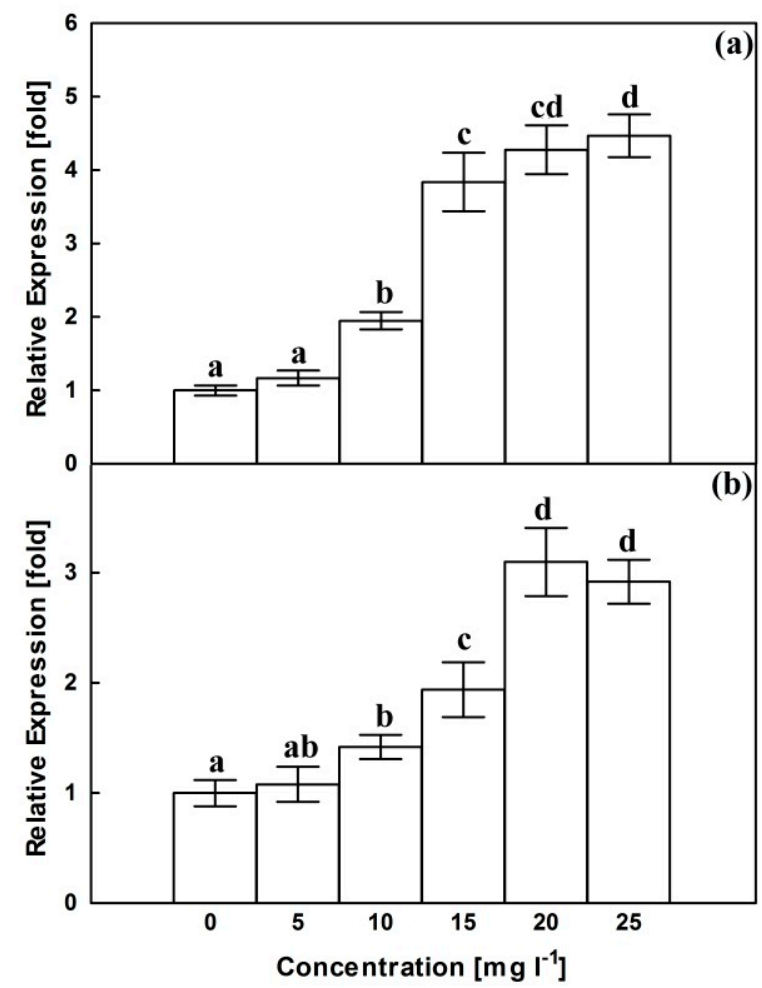

Figure 3. Effects of AgNPs at concentrations of 5, 10, 15, 20 and $25 \mathrm{mg} \mathrm{L}^{-1}$ on relative expression of CrMPK3 gene (a) and STR gene (b) of $C$. roseus cell suspension cultures. Means \pm standard deviations (SDs), $\mathrm{n}=3$, Values followed by the same small letter within each column are not significantly different at $p \leq 0.05$.

\subsection{Alkaloids Content}

Control cultures accumulate about $3 \mathrm{mg}$ alkaloids in each gram of dried cells and about $35 \mathrm{mg}$ othese secondary metabolites in each liter liquid growth medium after filtering the cells (Figure 4). Cellular accumulation of alkaloids remained insignificantly changed at $5 \mathrm{mg} \mathrm{L}^{-1}$; however, higher AgNPs concentrations were accompanied with significant enhancements in alkaloids accumulation in cells to reach 1.42 folds of the corresponding control at $25 \mathrm{mg} \mathrm{L}^{-1}$. Alkaloids accumulation in growth medium declined significantly at $5 \mathrm{mg} \mathrm{L}^{-1}$ and remained comparaple with corresponding control upon exposure to AgNPs at $10 \mathrm{mg} \mathrm{L}^{-1}$. Above $10 \mathrm{mg} \mathrm{L}^{-1}$, AgNPs significantly enhanced accumulation of alkaloids in growth medium reaching about 1.7 folds of the corresponding control at $25 \mathrm{mg} \mathrm{L}^{-1}$.

\subsection{Antioxidant Enzymes}

APX activity significantly increased more or less gradually following exposure to the increasing AgNPs concentrations reaching about 3.5 folds of control at $25 \mathrm{mg} \mathrm{L}^{-1}$ (Figure 5a). Assuming a slightly different trend, SOD activity increased in response to AgNPs treatments reaching a maximum of about 2.5 folds of control at $25 \mathrm{mg} \mathrm{L}^{-1}$ (Figure 5b). 


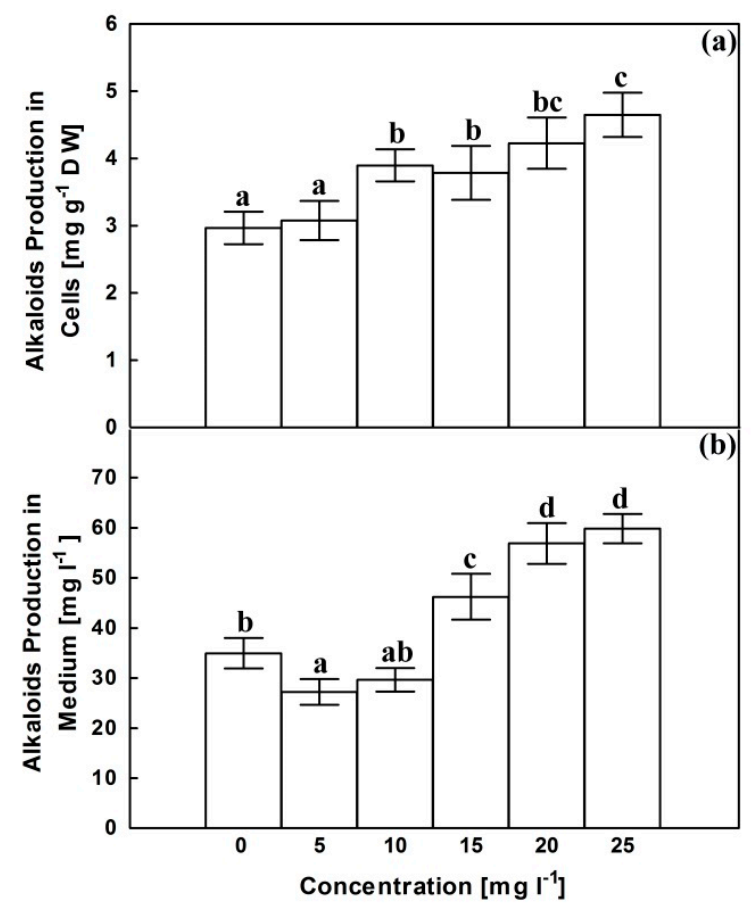

Figure 4. Effects of AgNPs at concentrations of 5, 10, 15, 20 and $25 \mathrm{mg} \mathrm{L}^{-1}$ on alkaloids content in dried cells (a) and growth medium (b) of C. roseus cell suspension cultures. Means \pm standard deviations (SDs), $\mathrm{n}=3$, Values followed by the same small letter within each column are not significantly different at $p \leq 0.05$.

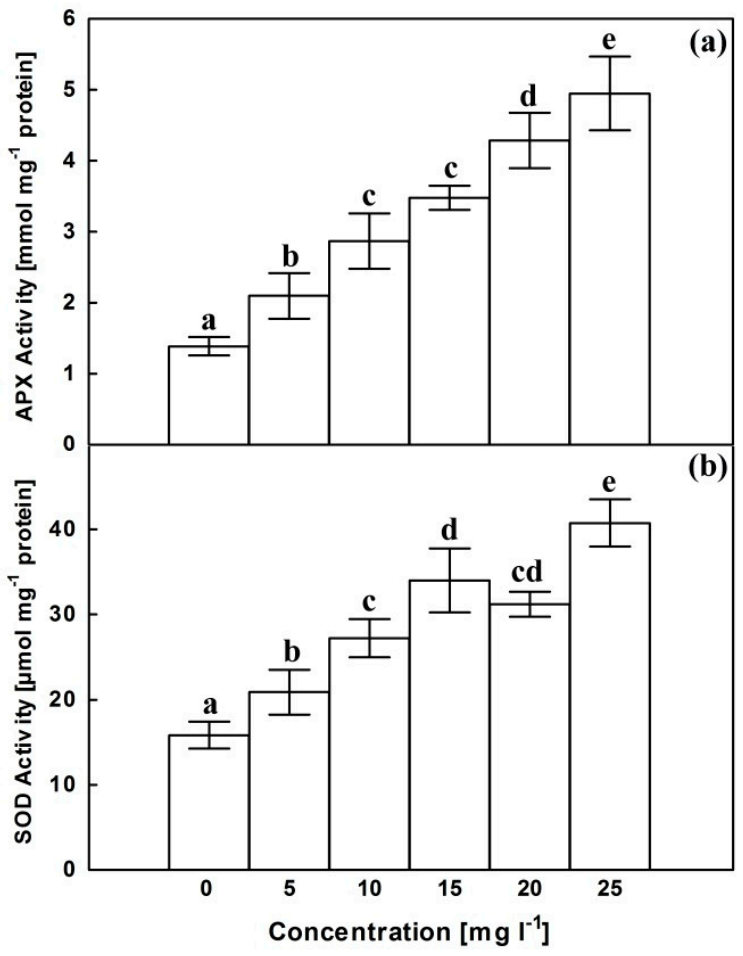

Figure 5. Effects of AgNPs at concentrations of 5, 10, 15, 20 and $25 \mathrm{mg} \mathrm{L}^{-1}$ on APX activity (a) and SOD activity (b) of $C$. roseus cell suspension cultures. Means \pm standard deviations (SDs), $\mathrm{n}=3$, Values followed by the same small letter within each column are not significantly different at $p \leq 0.05$.

Correlation analysis (Table 1) reflected significant negative Pearson correlations between AgNPs concentration and growth parameters, while all other concerned parameters appeared to be positively correlated with the concentration of AgNPs. Similar correlations 
were demonstrated for each of $\mathrm{H}_{2} \mathrm{O}_{2}$ and MDA contents with other parameters. Positive correlations were documented between CrMPK3 expression and STR expression as well as alkaloids content, either in cells or secreted in growth medium.

Table 1. Pearson correlation matrix for AgNPs concentration and different evaluated parameters.

\begin{tabular}{|c|c|c|c|c|c|c|c|c|c|c|}
\hline & $\begin{array}{l}\text { AgNPs } \\
\text { Conc. }\end{array}$ & $\begin{array}{c}\text { Fresh } \\
\text { Weight }\end{array}$ & $\begin{array}{c}\text { Dry } \\
\text { Weight }\end{array}$ & $\begin{array}{c}\mathrm{H}_{2} \mathrm{O}_{2} \\
\text { Content }\end{array}$ & $\begin{array}{c}\text { MDA } \\
\text { Content }\end{array}$ & $\begin{array}{c}\text { APX } \\
\text { Activity }\end{array}$ & $\begin{array}{c}\text { SOD } \\
\text { Activity }\end{array}$ & $\begin{array}{l}\text { CrMPK3 } \\
\text { Expression }\end{array}$ & $\begin{array}{c}S T R \\
\text { Expression }\end{array}$ & $\begin{array}{l}\text { Alkaloids } \\
\text { in Cells }\end{array}$ \\
\hline $\begin{array}{l}\text { Fresh Weight } \\
\text { Dry Weight }\end{array}$ & $\begin{array}{l}-0.874 * \\
-0.839 *\end{array}$ & $0.948 *$ & & & & & & & & \\
\hline $\mathrm{H}_{2} \mathrm{O}_{2}$ Content & $0.883 *$ & $\begin{array}{c}-0.848 \\
*\end{array}$ & -0.790 * & & & & & & & \\
\hline MDA Content & 0.928 * & $\underset{*}{-0.848}$ & -0.852 * & 0.841 * & & & & & & \\
\hline APX activity & 0.974 * & $\underset{*}{-0.813}$ & $-0.786^{*}$ & $0.898^{*}$ & $0.941 *$ & & & & & \\
\hline SOD activity & $0.933 *$ & $\begin{array}{c}-0.808 \\
*\end{array}$ & -0.767 * & $0.753 *$ & 0.890 * & 0.907 * & & & & \\
\hline CrMPKЗExpression & 0.950 * & $-\underset{*}{-0.885}$ & -0.883 * & $0.809 *$ & $0.904 *$ & $0.928 *$ & $0.883 *$ & & & \\
\hline STRExpression & $0.926^{*}$ & $\underset{*}{-0.819}$ & $-0.854 *$ & $0.828 *$ & $0.869 *$ & $0.908 *$ & $0.776^{*}$ & $0.904 *$ & & \\
\hline Alkaloids in cells & $0.883 *$ & $\underset{*}{-0.802}$ & -0.722 * & $0.787 *$ & 0.778 * & $0.853 *$ & $0.892 *$ & $0.821 *$ & $0.767 *$ & \\
\hline $\begin{array}{l}\text { Alkaloids in } \\
\text { medium }\end{array}$ & $0.860 *$ & $\underset{*}{-0.814}$ & $-0.844^{*}$ & $0.685^{*}$ & $0.835^{*}$ & $0.834 *$ & $0.763 *$ & $0.902 *$ & $0.927 *$ & $0.751 *$ \\
\hline
\end{tabular}

${ }^{*}$ Correlation is significant at the 0.05 level.

\section{Discussion}

Results of the present investigation reflected a biphasic effect of AgNPs on the growth of $C$. roseus cells. The available literatures provide contradictory results for the impact of AgNPs on plant growth [20]. Such effect seems to vary with particle size, shape, and concentration and is complicated with the treated plant material. The growth stimulation observed at low concentration, as shown in Figure 1, can be explained in light of the study conducted by Castro-González et al. [30] on stevia (Stevia rebaudiana B.) in vitro seedlings. The authors attributed the growth-promoting effect of low concentrations of AgNPs to inhibition of ethylene biosynthesis and improvement of nutrient accumulation and antioxidant metabolism.

In the same context, Gupta et al. [31] related the growth promotion recorded for Oryza sativa seedlings following AgNPs treatments to the acompanied increase in antioxidant enzymes activity that reduces oxidative stress and hydrogen peroxide content and prevents lipid peroxidation that appeared obviously in our results at $5 \mathrm{mg} \mathrm{L}^{-1}$. The inhibitory effect of AgNPs on ethylene biosynthesis [32] combined with the role of ethylene in signaling alkaloids production [33] can be used to explain the decrease in alkaloids accumulation in growth medium recorded in the current study.

Starting from $10 \mathrm{mg} \mathrm{L}^{-1}$, AgNPs showed a growth retarding effect (Figure 1) that can be attributed to the accompanied negatively correlated oxidative stress as manifested by an increase in $\mathrm{H}_{2} \mathrm{O}_{2}$ content and the resultant increase in lipid peroxidation products. These symptoms of oxidative stress were observed following exposure to AgNPs in rice seedlings [34], wheat callus [35], Pisum sativum seedlings [36], lettuce plants [37], Salvia officinalis seedlings [38], and Allium cepa root tips [39].

Recently, AgNPs have been a major revealer of bioactive molecule production. Many research reports have proven that the NPs could alter the secondary metabolism in plant and culture systems [40]. Despite the need for more research to understand the mechanism, some evidence suggests that NPs lead to the production of reactive oxygen species (ROS) and other second messengers, altering transcriptional regulation of plant secondary metabolism [41].

Plants typically produce $\mathrm{H}_{2} \mathrm{O}_{2}$ as a common metabolite for various cellular processes required for growth and development [42]. Nevertheless, $\mathrm{H}_{2} \mathrm{O}_{2}$ level rises significantly 
following exposure to different types of abiotic stress as a consequence of exaggerated energy and/or damaging of membrane system of chloroplast and mitochondria [43].

To cope with oxidative stress and to hunt the ROS, plants activate several metabolic pathways, including MAPK pathway, which is suggested as one of the plant's early responses to AgNPs treatment [41]. Results of the current study reflected a positive correlation between expression of CrMPK3 gene (Figure 3) and each of AgNPs concentration and $\mathrm{H}_{2} \mathrm{O}_{2}$ generation. $\mathrm{H}_{2} \mathrm{O}_{2}$-mediated induction of MAPK cascade was recorded in several plant species, including Brassica napus [44], Nicotiana tabacum [45], soybean leaves [46] and maize leaves [47]. $\mathrm{H}_{2} \mathrm{O}_{2}$ may activate MAPK pathway through the inactivation of MAPK repressors [48].

Induction of MAPK cascade transcriptionally elicits alkaloids biosynthesis to reduce ROS accumulation through their inhibitory effect on NADPH-oxidase, the key enzyme for ROS production [49]. Thus, our results reflected positive correlations between each of AgNPs concentration, $\mathrm{H}_{2} \mathrm{O}_{2}$ content, and expression of $\mathrm{CrMPK3}$ gene on one side and expression of STR gene as well as alkaloids content on the other side. Supporting these correlations, Khataee et al. [16] recorded that the enhancement of alkaloids accumulation following exposure to chromium was associated with an increase in lipid peroxidation and upregulation of MAPK and STR genes. In addition, Huerta-Heredia et al. [50] recorded an increase in alkaloids content in Uncaria tomentosa root cultures following exposure to $\mathrm{H}_{2} \mathrm{O}_{2}$. Working on the same plant, Vera-Reyes et al. [51] recorded the same findings in addition to documentation of accompanied-up regulation of STR gene.

The synchronization between up-regulation of CrMPK3 and STR genes and increase in alkaloids accumulation in C. roseus was recorded following exposure to different types of elicitors, including wounding, UV and methyl jasmonate [52], ethylene and copper [3], and silver nitrate combined with methyl jasmonate [14]. In a similar context, Fouad and Hafez [15] recorded a positive correlation between expression of CrMPK3 gene and alkaloids content in $C$. roseus suspension cultures experiencing oxidative stress symptoms following exposure to cobalt ions and cobalt nanoparticles.

The potential use of AgNPs to enhance alkaloids biosynthesis was proven in hairy root cultures of Datura metel [53] and Isatis constricta in vitro plants [54]. The increase in alkaloids content in cells without an associated increase in growth medium recorded in our results at $10 \mathrm{mg} \mathrm{L}^{-1}$ may reflect intracellular sinks for the newly synthesized alkaloids to cope the oxidative stress before immobilization to growth medium or suggest the ability of cells to retain alkaloids within intracellular specialized structures avoiding cytotoxicity with high concentrations in the growth medium [55].

Adding to antioxidant response against AgNPs-generated ROS, MAPKs stimulate expression and activities of antioxidant enzymes that are clearly demonstrated in positive correlations among AgNPs concentration, $\mathrm{H}_{2} \mathrm{O}_{2}$ content, expression of $\mathrm{CrMPK3}$ gene, and activities of APX and SOD in the present study. An increase in the activities of antioxidant enzymes following exposure to AgNPs was recorded by Nwaichi and Anosike [56] in Vigna subterranea plants, Barbasz et al. [35] in Pisum sativum seedlings, Ali et al. [26] in Caralluma tuberculata callus, and Jadczak et al. [57] in lavender in vitro plants. The involvement of MAPKs in the enhancement of antioxidant enzymes in response to oxidative stress is well documented in C. roseus suspension cultures [15], maize leaves [47], and wheat plants [58]. Summary for the action mechanism for AgNPs-mediated alkaloids biosynthesis in Catharanthus roseus in Figure 6 suggests induction of MAPKs genes that upregulate STR gene and enhances antioxidant enzemes. 


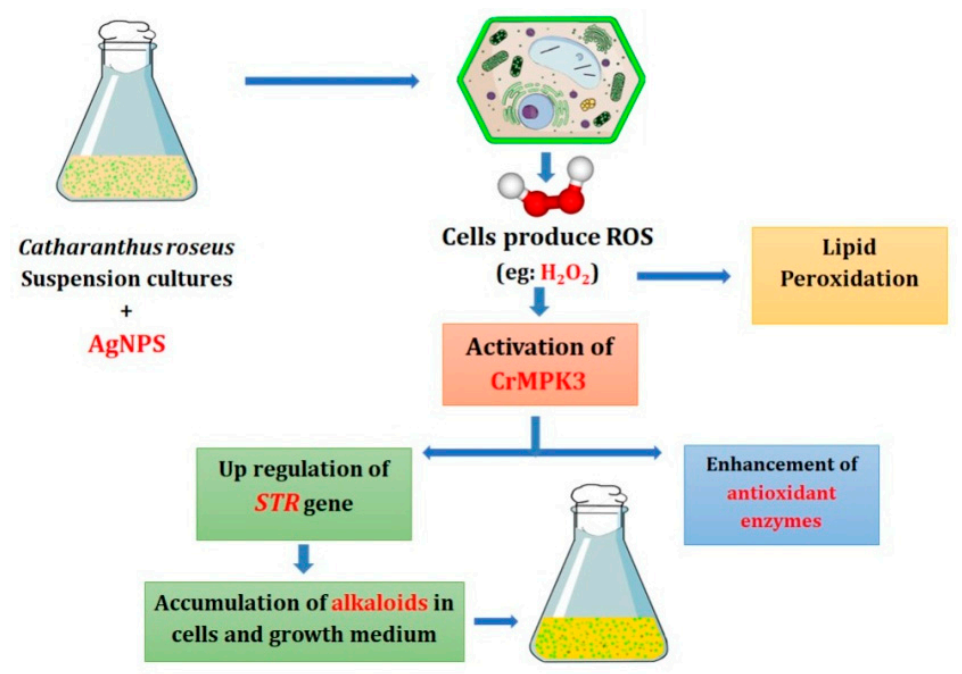

Figure 6. Summary for the action mechanism for AgNPs-mediated alkaloids biosynthesis in Catharanthus roseus.

\section{Materials and Methods}

\subsection{Silver Nanoparticles Characterization and Dispersion}

AgNPs were purchased from Nanotech, Cairo, Egypt, as roughly spherical 20-30 nm particles dispersed in deionized water (DW) in a concentration of $1 \mathrm{mg} / \mathrm{mL}$. Shape and size were confirmed with transmission electron microscopy (TEM) in our previous publication [59]. Experimental concentrations were prepared by diluting stock solution in DW, just before use, and sonication for $30 \mathrm{~min}$ at100 $\mathrm{W}$ and $30 \mathrm{kHz}$.

\subsection{Plant Material and Explant Preparation}

Healthy C. roseus seeds (generously afforded by Horticulture Research Institute, Agricultural Research Centre, Giza, Egypt) were surface sterilized sequentially in 70\% $(v / v)$ ethanol and $0.1 \%(\mathrm{~m} / \mathrm{v}) \mathrm{HgCl}_{2}$ for 1 and $10 \mathrm{~min}$, respectively. Sterilized seeds were rinsed several times in sterile distilled water after that transferred into $350 \mathrm{~mL}$ jars $(10-15$ seed per jar) containing germination medium. The medium was Murashige, and Skoog salts and vitamins [60] enrich with sucrose $\left(30 \mathrm{gL}^{-1}\right)$ and solidified with agar $\left(7 \mathrm{gL}^{-1}\right)$. The medium was autoclaved for $20 \mathrm{~min}$ at $121^{\circ} \mathrm{C}$ after $\mathrm{pH}$ adjustment at 5.8. Cultures were incubated at $25 \pm 2{ }^{\circ} \mathrm{C}$ and lighted at $30 \mu \mathrm{mol} \mathrm{m}^{-2} \mathrm{~s}^{-1}$ with $16 / 8 \mathrm{~h}$ photoperiod. After one week, seedlings were used as a source of hypocotyl explants.

\subsection{Tissue Cultures and Silver Treatments}

Cultures were established as described by Fouad and Hafez [61]. Calli were initiated on hypocotyl explants using callus induction medium of germination medium to which $0.5 \mathrm{mg} . \mathrm{L}^{-1}$ kinetin and $1.0 \mathrm{mgL}^{-1}$ of each of 2,4- dichlorophenoxyacetic acid $(2,4-\mathrm{D})$ and indole acetic acid (IAA) were added. Cultures were maintained in dark at $25 \pm 2{ }^{\circ} \mathrm{C}$ for one month; then, the originated calli were subcultured on the same but fresh medium with time intervals of one month under the same growth conditions. Cell suspension cultures were initiated in $500 \mathrm{~mL}$ flasks, each containing $200 \mathrm{~mL}$ callus induction medium lacking agar. Each flask was aseptically inoculated with $10 \mathrm{~g}$ calli then placed on an orbital shaker at $130 \mathrm{rpm}$. Every 10 days, cultures were divided into $20 \mathrm{~mL}$ aliquots that transferred to $180 \mathrm{~mL}$ fresh medium for subculture. After one week of the fourth subculture, filtersterilized aqueous AgNPs solution was aseptically introduced into cultures to reach a final concentration of 5, 10, 15, 20 and $25 \mathrm{mgL}^{-1}$. In control cultures, AgNPs were replaced with DW. Cells were collected, by filtration, for different analyses 4 and $72 \mathrm{~h}$ after applying silver treatments. The $4 \mathrm{~h}$ treatment was dedicated for real-time quantitative PCR while $72 \mathrm{~h}$ treatment was devoted for other measurements. Fresh weights were quantified, then cells were crushed into a fine powder with the aid of liquid nitrogen and stored at $-80^{\circ} \mathrm{C}$ till 
used. Dry weights were determined after a drying step at $50{ }^{\circ} \mathrm{C}$ till unchangeable weight. Dried cells and liquid growth medium were utilized to quantify alkaloids accumulated in cells and excreted in medium, respectively.

\section{4. $\mathrm{H}_{2} \mathrm{O}_{2}$}

$\mathrm{H}_{2} \mathrm{O}_{2}$ content was quantified according to the method outlined by Loreto and Velikova [62]. $0.5 \mathrm{~g}$ cells were homogenized in $2.5 \mathrm{~mL}$ of freshly prepared trichloroacetic acid $(0.1 \%(w / v))$ in an ice bath. The homogenate was centrifuged for $20 \mathrm{~min}$ at $4{ }^{\circ} \mathrm{C}$ and 10,000 g. $0.5 \mathrm{~mL}$ of the clear supernatant was mixed with an equal volume of $10 \mathrm{mM}$ potassium phosphate buffer ( $\mathrm{pH} 7.0$ ) and $1 \mathrm{~mL}$ of $1.0 \mathrm{M} \mathrm{KI}$. The absorbance was recorded at $390 \mathrm{~nm}$, and the amount of $\mathrm{H}_{2} \mathrm{O}_{2}$ (nmol g ${ }^{-1}$ fresh weight) was computed based on a standard curve constructed using different known concentrations of $\mathrm{H}_{2} \mathrm{O}_{2}$.

\subsection{Lipid Peroxidation Assay}

Lipid peroxidation was evaluated by quantification of malondialdehyde (MDA) formation employing the thio $\neg$ barbituric acid method Stewart and Bewley [63]. Liquid nitrogen-grinded cells belonging to $72 \mathrm{~h}$ treatment were blended with $100 \mathrm{mM}$ Tris- $\mathrm{HCl}$ buffer, $\mathrm{pH} 7.4$, containing $1.5 \%(\mathrm{~m} / \mathrm{v})$ polyvinylpyrrolidone (PVP). The homogenate was filtered, then the filtrate was centrifuged for $15 \mathrm{~min}$ at $15,000 \times g .1 \mathrm{~mL}$ transparent supernatant was incubated at $90{ }^{\circ} \mathrm{C}$ with $4 \mathrm{~mL}$ of $20 \%(\mathrm{~m} / \mathrm{v})$ trichloroacetic acid containing thiobarbituric acid in a concentration of $0.5 \%(\mathrm{~m} / \mathrm{v}) .30 \mathrm{~min}$ later, tubes were cooled and centrifuged for $15 \mathrm{~min}$ at $15,000 \times \mathrm{g}$. The MDA concentration was computed in the supernatant based on its extinction coefficient of $155 \mathrm{mM}^{-1} \mathrm{~cm}^{-1}$, and absorbance was read at $532 \mathrm{~nm}$ after subtraction of nonspecific absorbance at $600 \mathrm{~nm}$.

\subsection{Antioxidant Enzymes and Soluble Proteins}

Stored frozen powder of $72 \mathrm{~h}$ treatment was mixed with extraction solution of $50 \mathrm{mM}$ potassium phosphate buffer ( $\mathrm{pH} 7.8), 0.2 \mathrm{mM}$ EDTA and 1\% PVP $(m / v)$ [64]. The homogenate was centrifuged at $4{ }^{\circ} \mathrm{C}$ for $15 \mathrm{~min}$ at $20,000 \times g$ then the clear supernatant was used for assessment of ascorbate peroxidase (APX) and SOD activities as well as quantification of soluble proteins content.

Ascorbate peroxidase (APX) activity was assessed according to the protocol outlined by Nakano and Asada [65] using a reaction mixture of $50 \mathrm{mM}$ phosphate buffer, $\mathrm{pH} 7.0$, $0.5 \mathrm{mM}$ ascorbate, $1.2 \mathrm{mM} \mathrm{H}_{2} \mathrm{O}_{2}$, and $0.1 \mathrm{mM}$ EDTA. The rate of decrease in oxidised ascorbate absorbance was recorded at $290 \mathrm{~nm}$, and APX activity was computed using the extinction coefficient of $2.8 \mathrm{mM}^{-1} \mathrm{~cm}^{-1}$ for ascorbate. SOD activity was evaluated according to the method described by Beauchami and Fridovich [66] through monitoring the inhibition of photochemical reduction of nitroblue tetrazolioum (NBT). The assay was conducted using a reaction mixture of $50 \mathrm{mM}$ phosphate buffer ( $\mathrm{pH} 7.8$ ), $33 \mathrm{mM} \mathrm{NBT}$, $0.66 \mathrm{mM}$ Na-EDTA, $10 \mathrm{mM}$ methionine, and $3.3 \mathrm{mM}$ riboflavin at a light intensity of $300 \mu \mathrm{mol} \mathrm{m} \mathrm{m}^{-2} \mathrm{~s}^{-1}$. After $10 \mathrm{~min}$ at $25^{\circ} \mathrm{C}$, the change in OD was recorded at $560 \mathrm{~nm} .50 \%$ inhibition in NBT reduction was defined as one SOD unit [67].

Soluble proteins were estimated at $750 \mathrm{~nm}$ as outlined by Lowry et al. [68] employing Folin-Ciocaltcau reagent and bovine serum albumin-based calibration curve.

\subsection{Alkaloid Extraction and Determination}

Alkaloid extraction and determination was carried out, as described by Lee et al. [69] for dry weights and broth of $72 \mathrm{~h}$ treatments. Fine powder of oven-dry cells was extracted three times in methanol. The three extracts were mixed then the solvent was vacuumevaporated. In the separating funnel, the residue was shaken in acid water $(\mathrm{pH} 3)$ and petroleum ether. The aqueous phase was collected alkalinized to $\mathrm{pH}$ of 8.5 using $1 \mathrm{M}$ $\mathrm{NaOH}$, then total alkaloids were extracted with chloroform in a subsequent step. The collected liquid growth medium was acidified to $\mathrm{pH} 3$ and shaked with petroleum ether; then extraction was proceeded as described for dried cells. Total alkaloids content was 
computed by comparing OD recorded at $280 \mathrm{~nm}$ with an ajmalicine (Sigma-Aldrich, St. Louis, MO, USA)-based standard curve.

\subsection{Real-Time Quantitative PCR}

Fresh cells collected from $4 \mathrm{~h}$ treatments were used for total RNA extraction with the aids of Direct-zol ${ }^{\mathrm{TM}}$ RNA MiniPrep (http: / / www.zymoresearch.com (accessed on 10 October 2020)). After a purification step, residual genomic DNA was eliminated using DNase (Fermentas, Waltham, MA, USA) then RNA purity and concentration were evaluated using Nanodrop spectrophotometer (ND-2000c, Thermo Fisher Scientific, Wilmington, DE, USA). One $\mu \mathrm{g}$ purified RNA was devoted for cDNA synthesis employing Sensi $\neg \mathrm{FAST}^{\mathrm{TM}}$ cDNA synthesis kit (http:/ / www.bioline.com (accessed on 10 October 2020)). CrMPK3 and STR cDNAs were quantitatively amplified with the aid of a Mx3000P (Stratagene, CA, USA) qPCR system using specific primers (Table 2) [55]. The transcription level of actin was used as an endogenous control to which the transcription level of CrMPK3 and STR genes were normalized using the $2^{-\Delta \Delta C t}$ method [70]. The amplification protocol consisted of 40 amplification cycles $\left(95^{\circ} \mathrm{C}\right.$ for $15 \mathrm{~s}$ and $60^{\circ} \mathrm{C}$ for $60 \mathrm{~s}$ ) preceded by $95{ }^{\circ} \mathrm{C}$ for $10 \mathrm{~min}$. Expression estimated in cells collected from control cultures was employed as a quantification unit.

Table 2. List of primers used for qRT-PCR $\left(5^{\prime}-3^{\prime}\right)$.

\begin{tabular}{cc}
\hline Gene & Primers Sequence \\
\hline Actin & $5^{\prime}$-CTATGTTCCCAGGTATTGCAGATAGA-3' \\
CrMPK3 & $5^{\prime}$-GCTGCTTGGAGCCAAAGC-3 ${ }^{\prime}$ \\
& $5^{\prime}$ ACGAAATGAGGATGCAAAAAGATAC-3' \\
STR & $5^{\prime}$-TGCTAACTGCTGACGAGGGAAT-3' \\
& $5^{\prime}$-TGCTTCACTCCCATCATTTACAGT-3 ${ }^{\prime}$ \\
& $5^{\prime}$-CTGCCATCATGGATTTAGATTCAG-3' \\
\hline
\end{tabular}

\subsection{Statistical Analysis}

Results of all treatments were exhibited as the mean of three replicates \pm standard deviation (SD). Significant differences between different treatments was tested using the least significant difference (LSD) post-hoc test at level of significance set at $p \leq 0.05$ using SPSS v. 14. Correlations between parameters were calculated using Minitab v. 10.0 software based on Pearson correlation at $p$ values $<0.05$.

\section{Conclusions}

Thus, we can conclude that exposure to AgNPs was associated with oxidative stress manifested in an increase in $\mathrm{H}_{2} \mathrm{O}_{2}$ content and lipid peroxidation products that provoked antioxidant defense through MAPK cascade represented by CrMPK3. The induced MAPK transcriptionally induces alkaloids biosynthetic genes, including STR gene enhancing alkaloids accumulation to prevent ROS formation. In addition, the induced MAPK provoked antioxidant enzymes to scavenge the generated ROS. The results suggest a mechanism for the potential role of AgNPs in the enhancement of alkaloids accumulation in plant cells through a signaling pathway that involves $\mathrm{H}_{2} \mathrm{O}_{2}$ and MAPKs, leading to up-regulation of the biosynthetic genes, including STR gene.

Author Contributions: Conceptualization, A.F. and T.K.; methodology, A.F., T.K., A.E.H., E.A. and E.K.; software, A.F., T.K., E.A. and E.K.; validation, A.F., T.K., E.A. and E.K.; formal analysis, A.F. and T.K.; investigation, A.F., T.K., E.A. and E.K.; resources, A.F., T.K., A.E.H., E.A. and E.K.; data curation, A.F., T.K., A.E.H., E.A. and E.K.; writing—original draft preparation, A.F.; writing—review and editing, T.K.; visualization, A.F., E.A. and E.K.; supervision, A.F. and T.K. All authors have read and agreed to the published version of the manuscript.

Funding: This research received no external funding.

Institutional Review Board Statement: Not applicable. 
Informed Consent Statement: Not applicable.

Data Availability Statement: Not applicable.

Acknowledgments: Taif University Researchers Supporting Project Number (TURSP-2020/307), Taif University, Taif, Saudi Arabia.

Conflicts of Interest: The authors declare no conflict of interest.

\section{References}

1. Pan, Q.; Mustafa, N.R.; Tang, K.; Choi, Y.H.; Verpoorte, R. Monoterpenoid Indole Alkaloids Biosynthesis and Its Regulation in Catharanthus roseus: A Literature Review from Genes to Metabolites. Phytochem. Rev. 2016, 15, 221-250. [CrossRef]

2. Kaushik, N.K.; Kaushik, N.; Attri, P.; Kumar, N.; Kim, C.H.; Verma, A.K.; Choi, E.H. Biomedical Importance of Indoles. Molecules 2013, 18, 6620-6662. [CrossRef]

3. Pan, Y.-J.; Liu, J.; Guo, X.-R.; Zu, Y.-G.; Tang, Z.-H. Gene Transcript Profiles of the TIA Biosynthetic Pathway in Response to Ethylene and Copper Reveal Their Interactive Role in Modulating TIA Biosynthesis in Catharanthus roseus. Protoplasma 2015, 252, 813-824. [CrossRef]

4. Ghorbanpour, M.; Hatami, M.; Hatami, M. Activating Antioxidant Enzymes, Hyoscyamine and Scopolamine Biosynthesis of Hyoscyamus Niger L. Plants with Nano-Sized Titanium Dioxide and Bulk Application. Acta Agric. Slov. 2015, 105, 23-32. [CrossRef]

5. Zhu, W.; Yang, B.; Komatsu, S.; Lu, X.; Li, X.; Tian, J. Binary Stress Induces an Increase in Indole Alkaloid Biosynthesis in Catharanthus roseus. Front. Plant Sci. 2015, 6, 582. [CrossRef] [PubMed]

6. Austen, N.; Walker, H.J.; Lake, J.A.; Phoenix, G.K.; Cameron, D.D. The Regulation of Plant Secondary Metabolism in Response to Abiotic Stress: Interactions Between Heat Shock and Elevated CO2. Front. Plant Sci. 2019, 10, 1463. [CrossRef]

7. Isah, T. Stress and Defense Responses in Plant Secondary Metabolites Production. Biol. Res. 2019, 52. [CrossRef] [PubMed]

8. Berni, R.; Luyckx, M.; Xu, X.; Legay, S.; Sergeant, K.; Hausman, J.-F.; Lutts, S.; Cai, G.; Guerriero, G. Reactive Oxygen Species and Heavy Metal Stress in Plants: Impact on the Cell Wall and Secondary Metabolism. Environ. Exp. Bot. 2019, 161, 98-106. [CrossRef]

9. Hatami, M.; Ghorbanpour, M. Retracted Chapter: Changes in Phytochemicals in Response to Rhizospheric Microorganism Infection. Microb. -Mediat. Induc. Syst. Resist. Plants 2016, 1-14. [CrossRef]

10. Lajayer, B.A.; Ghorbanpour, M.; Nikabadi, S. Heavy Metals in Contaminated Environment: Destiny of Secondary Metabolite Biosynthesis, Oxidative Status and Phytoextraction in Medicinal Plants. Ecotoxicol. Environ. Saf. 2017, 145, 377-390. [CrossRef] [PubMed]

11. Srivastava, N.; Srivastava, A. Influence of Some Heavy Metals on Growth, Alkaloid Content and Composition in Catharanthus roseus L. Indian J. Pharm. Sci. 2010, 72, 775. [CrossRef] [PubMed]

12. Fathalla, M.; Abd-El Kawy, A.; Taha, H. Effect of Heavy Metal $(\mathrm{HgCl})$ on 2 Accumulation and Production of Total Indole Alkaloids, Vinblastine, and/or Vincristine from Egyptian Catharanthus roseus (L.) G. Don. Calli Cultures. J. Appl. Sci. Res. $2011,7,542-549$.

13. Chen, Q.; Wu, K.; Tang, Z.; Guo, Q.; Guo, X.; Wang, H. Exogenous Ethylene Enhanced the Cadmium Resistance and Changed the Alkaloid Biosynthesis in Catharanthus roseus Seedlings. Acta Physiol. Plant. 2017, 39, 1-12. [CrossRef]

14. Paeizi, M.; Karimi, F.; Razavi, K. Changes in Medicinal Alkaloids Production and Expression of Related Regulatory and Biosynthetic Genes in Response to Silver Nitrate Combined with Methyl Jasmonate in Catharanthus roseus in Vitro Propagated Shoots. Plant Physiol. Biochem. 2018, 132, 623-632. [CrossRef]

15. Fouad, A.S.; Hafez, R.M. Effect of Cobalt Nanoparticles and Cobalt Ions on Alkaloids Production and Expression of CrMPK3 Gene in Catharanthus roseus Suspension Cultures. Cell. Mol. Biol. 2018, 64, 62-69. [CrossRef] [PubMed]

16. Khataee, E.; Karimi, F.; Razavi, K. Chromium-Induced Alkaloid Production in Catharanthus roseus (L.) G. Don in Vitro Cultured Shoots and Related Gene Expression Patterns Particularly for the Novel Gene GS. Acta Agric. Slov. 2019, 113, 95-108. [CrossRef]

17. Zhang, X.; Mi, X.; Chen, C.; Wang, H.; Guo, W. Identification on Mitogen-Activated Protein Kinase Signaling Cascades by Integrating Protein Interaction with Transcriptional Profiling Analysis in Cotton. Sci. Rep. 2018, 8, 1-14. [CrossRef]

18. Khataee, E.; Karimi, F.; Razavi, K. Alkaloids Production and Antioxidant Properties in Catharanthus roseus (L.) G. Don. Shoots and Study of Alkaloid Biosynthesis-Related Gene Expression Levels in Response to Methyl Jasmonate and Putrescine Treatments as Eco-Friendly Elicitors. Biol. Futur. 2019, 70, 38-46. [CrossRef] [PubMed]

19. Schmid, G. Nanoparticles: From Theory to Application; John Wiley \& Sons: Hoboken, NJ, USA, 2011.

20. Yan, A.; Chen, Z. Impacts of Silver Nanoparticles on Plants: A Focus on the Phytotoxicity and Underlying Mechanism. Int. J. Mol. Sci. 2019, 20, 1003. [CrossRef] [PubMed]

21. Abdel-Azeem, A.; Nada, A.A.; O'donovan, A.; Thakur, V.K.; Elkelish, A. Mycogenic Silver Nanoparticles from Endophytic Trichoderma Atroviride with Antimicrobial Activity. J. Renew. Mater. 2020, 8, 171. [CrossRef]

22. Salem, S.S.; El-Belely, E.F.; Niedba \la, G.; Alnoman, M.M.; Hassan, S.E.-D.; Eid, A.M.; Shaheen, T.I.; Elkelish, A.; Fouda, A. Bactericidal and In-Vitro Cytotoxic Efficacy of Silver Nanoparticles (Ag-NPs) Fabricated by Endophytic Actinomycetes and Their Use as Coating for the Textile Fabrics. Nanomaterials 2020, 10, 2082. [CrossRef] [PubMed]

23. Soliman, M.; Qari, S.H.; Abu-Elsaoud, A.; El-Esawi, M.; Alhaithloul, H.; Elkelish, A. Rapid Green Synthesis of Silver Nanoparticles from Blue Gum Augment Growth and Performance of Maize, Fenugreek, and Onion by Modulating Plants Cellular Antioxidant Machinery and Genes Expression. Acta Physiol. Plant. 2020, 42, 1-16. [CrossRef] 
24. Jamshidi, M.; Ghanati, F. Taxanes Content and Cytotoxicity of Hazel Cells Extract after Elicitation with Silver Nanoparticles. Plant Physiol. Biochem. 2017, 110, 178-184. [CrossRef] [PubMed]

25. Chung, I.-M.; Rajakumar, G.; Thiruvengadam, M. Effect of Silver Nanoparticles on Phenolic Compounds Production and Biological Activities in Hairy Root Cultures of Cucumis Anguria. Acta Biol. Hung. 2018, 69, 97-109. [CrossRef]

26. Ali, A.; Mohammad, S.; Khan, M.A.; Raja, N.I.; Arif, M.; Kamil, A.; Mashwani, Z.-R. Silver Nanoparticles Elicited in Vitro Callus Cultures for Accumulation of Biomass and Secondary Metabolites in Caralluma Tuberculata. Artif. Cells Nanomed. Biotechnol. 2019, 47, 715-724. [CrossRef]

27. Zahir, A.; Nadeem, M.; Ahmad, W.; Giglioli-Guivarc'h, N.; Hano, C.; Abbasi, B.H. Chemogenic Silver Nanoparticles Enhance Lignans and Neolignans in Cell Suspension Cultures of Linum usitatissimum L. Plant Cell Tissue Organ Cult. 2019, 136, 589-596. [CrossRef]

28. Naeem, M.; Aftab, T.; Khan, M.M.A. Catharanthus Roseus; Springer: Berlin/Heidelberg, Germany, 2017.

29. Hussain, M.S.; Fareed, S.; Saba Ansari, M.; Rahman, A.; Ahmad, I.Z.; Saeed, M. Current Approaches toward Production of Secondary Plant Metabolites. J. Pharm. Bioallied Sci. 2012, 4, 10. [CrossRef] [PubMed]

30. Castro-González, C.G.; Sánchez-Segura, L.; Gómez-Merino, F.C.; Bello-Bello, J.J. Exposure of Stevia (Stevia Rebaudiana B.) to Silver Nanoparticles in Vitro: Transport and Accumulation. Sci. Rep. 2019, 9, 1-10. [CrossRef]

31. Gupta, S.D.; Agarwal, A.; Pradhan, S. Phytostimulatory Effect of Silver Nanoparticles (AgNPs) on Rice Seedling Growth: An Insight from Antioxidative Enzyme Activities and Gene Expression Patterns. Ecotoxicol. Environ. Saf. 2018, 161, 624-633. [CrossRef] [PubMed]

32. Hassan, F.; Ali, E.; El-Deeb, B. Improvement of Postharvest Quality of Cut Rose Cv.'First Red'by Biologically Synthesized Silver Nanoparticles. Sci. Hortic. 2014, 179, 340-348. [CrossRef]

33. Liu, J.; Liu, Y.; Wang, Y.; Zhang, Z.-H.; Zu, Y.-G.; Efferth, T.; Tang, Z.-H. The Combined Effects of Ethylene and MeJA on Metabolic Profiling of Phenolic Compounds in Catharanthus roseus Revealed by Metabolomics Analysis. Front. Physiol. 2016, 7, 217. [CrossRef]

34. Thuesombat, P.; Hannongbua, S.; Ekgasit, S.; Chadchawan, S. Effects of Silver Nanoparticles on Hydrogen Peroxide Generation and Antioxidant Enzyme Responses in Rice. J. Nanosci. Nanotechnol. 2016, 16, 8030-8043. [CrossRef]

35. Barbasz, A.; Kreczmer, B.; Oćwieja, M. Effects of Exposure of Callus Cells of Two Wheat Varieties to Silver Nanoparticles and Silver Salt (AgNO 3). Acta Physiol. Plant. 2016, 38, 76. [CrossRef]

36. Tripathi, D.K.; Singh, S.; Singh, S.; Srivastava, P.K.; Singh, V.P.; Singh, S.; Prasad, S.M.; Singh, P.K.; Dubey, N.K.; Pandey, A.C.; et al. Nitric Oxide Alleviates Silver Nanoparticles (AgNps)-Induced Phytotoxicity in Pisum Sativum Seedlings. Plant Physiol. Biochem. 2017, 110, 167-177. [CrossRef] [PubMed]

37. Li, W.-Q.; Qing, T.; Li, C.-C.; Li, F.; Ge, F.; Fei, J.-J.; Peijnenburg, W.J. Integration of Subcellular Partitioning and Chemical Forms to Understand Silver Nanoparticles Toxicity to Lettuce (Lactuca Sativa L.) under Different Exposure Pathways. Chemosphere 2020, 258, 127349. [CrossRef] [PubMed]

38. Moazzami Farida, S.H.; Karamian, R.; Albrectsen, B.R. Silver Nanoparticle Pollutants Activate Oxidative Stress Responses and Rosmarinic Acid Accumulation in Sage. Physiol. Plant. 2020, 170, 415-432. [CrossRef]

39. Hafez, R.; Fouad, A. Mitigation of Genotoxic and Cytotoxic Effects of Silver Nanoparticles on Onion Root Tips Using Some Antioxidant Scavengers. Egypt. J. Bot. 2020, 60, 133-145. [CrossRef]

40. Rivero-Montejo, S.d.J.; Vargas-Hernandez, M.; Torres-Pacheco, I. Nanoparticles as Novel Elicitors to Improve Bioactive Compounds in Plants. Agriculture 2021, 11, 134. [CrossRef]

41. Marslin, G.; Sheeba, C.J.; Franklin, G. Nanoparticles Alter Secondary Metabolism in Plants via ROS Burst. Front. Plant Sci. 2017, 8, 832. [CrossRef]

42. Smirnoff, N.; Arnaud, D. Hydrogen Peroxide Metabolism and Functions in Plants. New Phytol. 2019, 221, 1197-1214. [CrossRef]

43. Černỳ, M.; Habánová, H.; Berka, M.; Luklová, M.; Brzobohatỳ, B. Hydrogen Peroxide: Its Role in Plant Biology and Crosstalk with Signalling Networks. Int. J. Mol. Sci. 2018, 19, 2812. [CrossRef]

44. Zhang, T.; Zhu, M.; Song, W.; Harmon, A.C.; Chen, S. Oxidation and Phosphorylation of MAP Kinase 4 Cause Protein Aggregation. Biochim. Et Biophys. Acta (BBA)-Proteins Proteom. 2015, 1854, 156-165. [CrossRef]

45. Matern, S.; Peskan-Berghoefer, T.; Gromes, R.; Kiesel, R.V.; Rausch, T. Imposed Glutathione-Mediated Redox Switch Modulates the Tobacco Wound-Induced Protein Kinase and Salicylic Acid-Induced Protein Kinase Activation State and Impacts on Defence against Pseudomonas Syringae. J. Exp. Bot. 2015, 66, 1935-1950. [CrossRef]

46. Xu, H.-Y.; Zhang, C.; Li, Z.-C.; Wang, Z.-R.; Jiang, X.-X.; Shi, Y.-F.; Tian, S.-N.; Braun, E.; Mei, Y.; Qiu, W.-L.; et al. The MAPK Kinase Kinase GmMEKK1 Regulates Cell Death and Defense Responses. Plant Physiol. 2018, 178, 907-922. [CrossRef]

47. Liu, J.; Wang, J.; Lee, S.; Wen, R. Copper-Caused Oxidative Stress Triggers the Activation of Antioxidant Enzymes via ZmMPK3 in Maize Leaves. PLoS ONE 2018, 13, e0203612. [CrossRef] [PubMed]

48. Liu, Y.; He, C. A Review of Redox Signaling and the Control of MAP Kinase Pathway in Plants. Redox Biol. 2017, 11, 192-204. [CrossRef] [PubMed]

49. Macáková, K.; Afonso, R.; Saso, L.; Mladěnka, P. The Influence of Alkaloids on Oxidative Stress and Related Signaling Pathways. Free Radic. Biol. Med. 2019, 134, 429-444. [CrossRef] [PubMed] 
50. Huerta-Heredia, A.A.; Marín-López, R.; Ponce-Noyola, T.; Cerda-García-Rojas, C.M.; Trejo-Tapia, G.; Ramos-Valdivia, A.C. Oxidative Stress Induces Alkaloid Production in Uncaria Tomentosa Root and Cell Cultures in Bioreactors. Eng. Life Sci. 2009, 9, 211-218. [CrossRef]

51. Vera-Reyes, I.; Huerta-Heredia, A.A.; Ponce-Noyola, T.; Flores-Sanchez, I.J.; Esparza-García, F.; Cerda-García-Rojas, C.M.; TrejoTapia, G.; Ramos-Valdivia, A.C. Strictosidine-Related Enzymes Involved in the Alkaloid Biosynthesis of Uncaria Tomentosa Root Cultures Grown under Oxidative Stress. Biotechnol. Prog. 2013, 29, 621-630. [CrossRef] [PubMed]

52. Raina, S.K.; Wankhede, D.P.; Jaggi, M.; Singh, P.; Jalmi, S.K.; Raghuram, B.; Sheikh, A.H.; Sinha, A.K. CrMPK3, a Mitogen Activated Protein Kinase from Catharanthus roseus and Its Possible Role in Stress Induced Biosynthesis of Monoterpenoid Indole Alkaloids. BMC Plant Biol. 2012, 12, 1-13. [CrossRef]

53. Shakeran, Z.; Keyhanfar, M.; Asghari, G.; Ghanadian, M. Improvement of Atropine Production by Different Biotic and Abiotic Elicitors in Hairy Root Cultures of Datura Metel. Turk. J. Biol. 2015, 39, 111-118. [CrossRef]

54. Karakaş, Ö. Effect of Silver Nanoparticles on Production of Indole Alkaloids in Isatis Constricta. Iran. J. Sci. Technol. Trans. A Sci. 2020, 44, 621-627. [CrossRef]

55. Mithöfer, A.; Boland, W. Plant Defense against Herbivores: Chemical Aspects. Annu. Rev. Plant Biol. 2012, 63, 431-450. [CrossRef] [PubMed]

56. Nwaichi, E.; Anosike, E. Plant Response on Exposure to Ag Nanoparticles: A Study with Vigna Subterranean. Biochem. Anal. Biochem 2016, 5, 1-6. [CrossRef]

57. Jadczak, P.; Kulpa, D.; Drozd, R.; Przewodowski, W.; Przewodowska, A. Effect of AuNPs and AgNPs on the Antioxidant System and Antioxidant Activity of Lavender (Lavandula Angustifolia Mill.) from In Vitro Cultures. Molecules 2020, 25, 5511. [CrossRef] [PubMed]

58. Dudziak, K.; Zapalska, M.; Börner, A.; Szczerba, H.; Kowalczyk, K.; Nowak, M. Analysis of Wheat Gene Expression Related to the Oxidative Stress Response and Signal Transduction under Short-Term Osmotic Stress. Sci. Rep. 2019, 9, 1-14. [CrossRef] [PubMed]

59. Fouad, A.; Hafez, R. The Effects of Silver Ions and Silver Nanoparticles on Cell Division and Expression of Cdc2 Gene in Allium Cepa Root Tips. Biol. Plant. 2018, 62, 166-172. [CrossRef]

60. Murashige, T.; Skoog, F. A Revised Medium for Rapid Growth and Bio Assays with Tobacco Tissue Cultures. Physiol. Plant. 1962, 15, 473-497. [CrossRef]

61. Fouad, A.S.; Hafez, R.M. Effects of Cobalt Ions and Cobalt Nanoparticles on Transient Expression of Gus Gene in Catharanthus roseus Suspension Cultures. J. Radiat. Res. Appl. Sci. 2020, 13, 765-775. [CrossRef]

62. Loreto, F.; Velikova, V. Isoprene Produced by Leaves Protects the Photosynthetic Apparatus against Ozone Damage, Quenches Ozone Products, and Reduces Lipid Peroxidation of Cellular Membranes. Plant Physiol. 2001, 127, 1781-1787. [CrossRef]

63. Stewart, R.R.; Bewley, J.D. Lipid Peroxidation Associated with Accelerated Aging of Soybean Axes. Plant Physiol. 1980, 65, 245-248. [CrossRef] [PubMed]

64. Gong, H.; Chen, G.; Li, F.; Wang, X.; Hu, Y.; Bi, Y. Involvement of G6PDH in Heat Stress Tolerance in the Calli from Przewalskia Tangutica and Nicotiana Tabacum. Biol. Plant. 2012, 56, 422-430. [CrossRef]

65. Nakano, Y.; Asada, K. Hydrogen Peroxide Is Scavenged by Ascorbate-Specific Peroxidase in Spinach Chloroplasts. Plant Cell Physiol. 1981, 22, 867-880.

66. Beauchamp, C.; Fridovich, I. Superoxide Dismutase: Improved Assays and an Assay Applicable to Acrylamide Gels. Anal. Biochem. 1971, 44, 276-287. [CrossRef]

67. Elkahoui, S.; Hernández, J.A.; Abdelly, C.; Ghrir, R.; Limam, F. Effects of Salt on Lipid Peroxidation and Antioxidant Enzyme Activities of Catharanthus roseus Suspension Cells. Plant Sci. 2005, 168, 607-613. [CrossRef]

68. Lowry, O.H.; Rosebrough, N.J.; Farr, A.L.; Randall, R.J. Protein Measurement with the Folin Phenol Reagent. J. Biol. Chem. 1951, 193, 265-275. [CrossRef]

69. Lee, S.; Cheng, K.; Scott, A. Effects of Bioregulators on Indole Alkaloid Biosynthesis in Catharanthus roseus Cell Culture. Phytochemistry 1981, 20, 1841-1843.

70. Livak, K.J.; Schmittgen, T.D. Analysis of Relative Gene Expression Data Using Real-Time Quantitative PCR and the 2- $\Delta \Delta C T$ Method. Methods 2001, 25, 402-408. [CrossRef] 